\title{
Mapping of West Siberian taiga wetland complexes using Landsat imagery: implications for methane emissions
}

\author{
Irina Evgenievna Terentieva ${ }^{1,{ }^{*}}$, Mikhail Vladimirovich Glagolev ${ }^{1,3,4,5}$, Elena Dmitrievna Lapshina $^{3}$, \\ Alexandr Faritovich Sabrekov ${ }^{2}$, and Shamil Maksyutov ${ }^{6}$ \\ ${ }^{1}$ Laboratory of Computational Geophysics, Tomsk State University, Tomsk, 643050, Russia \\ ${ }^{2}$ BIO-GEO-CLIM Laboratory, Tomsk State University, Tomsk, 643050, Russia \\ ${ }^{3}$ UNESCO Department 'Environmental Dynamics and Global Climate Changes', Yugra State University, \\ Khanty-Mansiysk, 628012, Russia \\ ${ }^{4}$ Institute of Forest Science Russian Academy of Sciences, Uspenskoe, 143030, Russia \\ ${ }^{5}$ Faculty of Soil Science, Moscow State University, Moscow, 119992, Russia \\ ${ }^{6}$ Center for Global Environmental Research, National Institute for Environmental Studies, Tsukuba, 305-8506, Japan \\ * previously published under the name I. E. Kleptsova
}

Correspondence to: Irina Evgenievna Terentieva (kleptsova@gmail.com)

Received: 5 November 2015 - Published in Biogeosciences Discuss.: 16 December 2015

Revised: 18 July 2016 - Accepted: 21 July 2016 - Published: 16 August 2016

\begin{abstract}
High-latitude wetlands are important for understanding climate change risks because these environments sink carbon dioxide and emit methane. However, fine-scale heterogeneity of wetland landscapes poses a serious challenge when generating regional-scale estimates of greenhouse gas fluxes from point observations. In order to reduce uncertainties at the regional scale, we mapped wetlands and water bodies in the taiga zone of The West Siberia Lowland (WSL) on a scene-by-scene basis using a supervised classification of Landsat imagery. Training data consist of highresolution images and extensive field data collected at 28 test areas. The classification scheme aims at supporting methane inventory applications and includes seven wetland ecosystem types comprising nine wetland complexes distinguishable at the Landsat resolution. To merge typologies, mean relative areas of wetland ecosystems within each wetland complex type were estimated using high-resolution images. Accuracy assessment based on 1082 validation polygons of $10 \times 10$ pixel size indicated an overall map accuracy of $79 \%$. The total area of the WSL wetlands and water bodies was estimated to be 52.4 Mha or $4-12 \%$ of the global wetland area. Ridge-hollow complexes prevail in WSL's taiga zone accounting for $33 \%$ of the total wetland area, followed by pine bogs or "ryams" $(23 \%)$, ridge-hollow-lake complexes $(16 \%)$, open fens $(8 \%)$, palsa complexes $(7 \%)$, open bogs
\end{abstract}

$(5 \%)$, patterned fens $(4 \%)$, and swamps $(4 \%)$. Various oligotrophic environments are dominant among wetland ecosystems, while poor fens cover only $14 \%$ of the area. Because of the significant change in the wetland ecosystem coverage in comparison to previous studies, a considerable reevaluation of the total $\mathrm{CH}_{4}$ emissions from the entire region is expected. A new Landsat-based map of WSL's taiga wetlands provides a benchmark for validation of coarse-resolution global land cover products and wetland data sets in high latitudes.

\section{Introduction}

High-latitude wetlands are important for understanding climate change mechanism as they provide long-term storage of carbon and emit a significant amount of methane. The West Siberia Lowland (WSL) is the world's largest high-latitude wetland system and experiences an accelerated rate of climate change (Solomon et al., 2007).

Poorly constrained estimates of wetland and lake area constitute a major uncertainty in estimating current and future greenhouse gas emissions (Melton et al., 2013; Turetsky et al., 2014; Petrescu et al., 2010). Although wetland extent in WSL has been reasonably well captured by global products based on topographic maps (Lehner and Döll, 2004; 
Matthews and Fung, 1987), mapping of fine-scale heterogeneity of WSL's wetland landscapes (Bohn et al., 2007) requires adding fine scale information on ecosystem functioning as made in wetland $\mathrm{CH}_{4}$ emission inventory (Glagolev et al., 2011) and estimates of net primary production (Peregon et al., 2008). Present land cover products fail to capture finescale spatial variability within WSL's wetlands due to the lack of details necessary for reliable productivity and emissions estimates. Frey and Smith (2007) mentioned inaccuracy of four global vegetation and wetland products, with the best agreement of only $56 \%$, with the high-resolution WSL Peatland Database (WSLPD; Sheng et al., 2004). Products derived primarily from coarse-resolution microwave remote sensing data (Prigent et al., 2007; Jones et al., 2010; Papa et al., 2010; Schroeder et al., 2010, 2015) generally map the presence of surface water in the landscape, thus overlooking non-inundated, $\mathrm{CH}_{4}$-emitting wetlands in which the water table is at or below the soil and/or peat or sphagnum surface. Because boreal peatlands do not experience prolonged inundation, such products underestimate their area (Krankina et al., 2008). Uncertainty in wetland inventory results in severe biases in $\mathrm{CH}_{4}$ emission estimates, the scale of differences has been shown by Bohn et al. (2015).

Modelers simulating methane emission are in need for high-resolution wetland maps that do not only delineate wetlands but also identify the major sub-types to which different environmental parameters could potentially be applied (Bohn et al., 2015). Several wetland maps have been used to define the wetland extent in WSL, however their application to net primary production (NPP) and methane emission inventories was accompanied by difficulties due to crude classification scheme, limited ground truth data and low spatial resolution. One peatland typology map that distinguishes several vegetation and microtopography classes and their mixtures was developed at the State Hydrological Institute (SHI) by Romanova et al. (1977). Peregon et al. (2005) digitized and complemented this map by estimating the fractional coverage of wetland structural components using Landsat images and aerial photographs for five test sites. However, the limited amount of fractional coverage data and coarse resolution still result in large uncertainties in upscaling methane fluxes (Kleptsova et al., 2012).

Our goal was to develop a multi-scale approach for mapping wetlands using Landsat imagery with a resolution of $30 \mathrm{~m}$ so the results could better meet the needs of land process modelling and other applications concerning methane emission from peatlands. In this study, the WSL taiga zone was chosen as the primary target for the land cover classification due to wetland abundance. The objectives were the following: first, to develop a consistent land cover of wetland classes and its structural components; second, to provide the foundation for environmental parameter upscaling (greenhouse gas inventories, carbon balance, NPP, net ecosystem exchange, biomass, etc) and validation of the process models.

\section{Materials and methods}

\subsection{Study region}

The West Siberian Lowland is a geographical region of Russia bordered by the Ural Mountains in the west and the Yenisey River in the east; the region covers 275 Mha within $62-89^{\circ} \mathrm{E}$ and $53-73^{\circ} \mathrm{N}$. Because of its vast expanse and flat terrain, the vegetation cover of the Lowland shows clear latitudinal zonation. According to Gvozdetsky (1968), the taiga zone is divided into three geobotanical subzones: northern taiga, middle taiga and southern taiga. Taiga corresponds to the raised string bog province and covers about $160 \mathrm{Mha}$ in the central part of the WS. It is characterized by flat terrain with elevations of 80 to $100 \mathrm{~m}$ above sea level rising to about $190 \mathrm{~m}$ in the "Siberian Uvaly" area. Average annual precipitation and evaporation over the region is about 450 500 and $200-400 \mathrm{~mm}$ respectively (National Atlas of Russia, 2008). The excess water supply and flat terrain with poor drainage provides favorable conditions for wetland formation. Comprehensive synthesis of Russian literature regarding the current state of the WSL peatlands, their development and sensitivity to climatic changes was made by Kremenetski et al. (2003).

\subsection{Classification methodology}

No single classification algorithm can be considered as optimal methodology for improving vegetation mapping; hence, the use of advanced classifier algorithms must be based on their suitability for achieving certain objectives in specific applications (Adam et al., 2009). Because mapping over large areas typically involves many satellite scenes, multiscene mosaicking is often used to group scenes into a single file set for further classification. This approach optimizes both the classification process and edge matching. However, large multi-scene mosaicking has essential drawback when applying to highly heterogeneous WSL wetlands. It creates a variety of spectral gradients within the file (Homer and Gallant, 2001), especially when the number of the appropriate scenes is limited. It results in spectral discrepancy that is difficult to overcome. In this study, the advantages of consistency in class definition of the scene-by-scene classification approach were considered to outweigh the inherent disadvantages of edge matching and processing labor. Thus, our entire analysis was performed on a scene-by-scene basis, similar to the efforts by Giri et al. (2011) and Gong et al. (2013).

For land cover consistency, data of the same year and season, preferably of the growing season peak (July) are required. However, the main complication was the low availability of good quality cloudless images of WSL during those periods. Scenes collected earlier than the 2000s were very few, so they were used as substitutes for places where no other suitable imagery could be found. Landsat-7 images received after 2003 were not used due to data gaps, while 

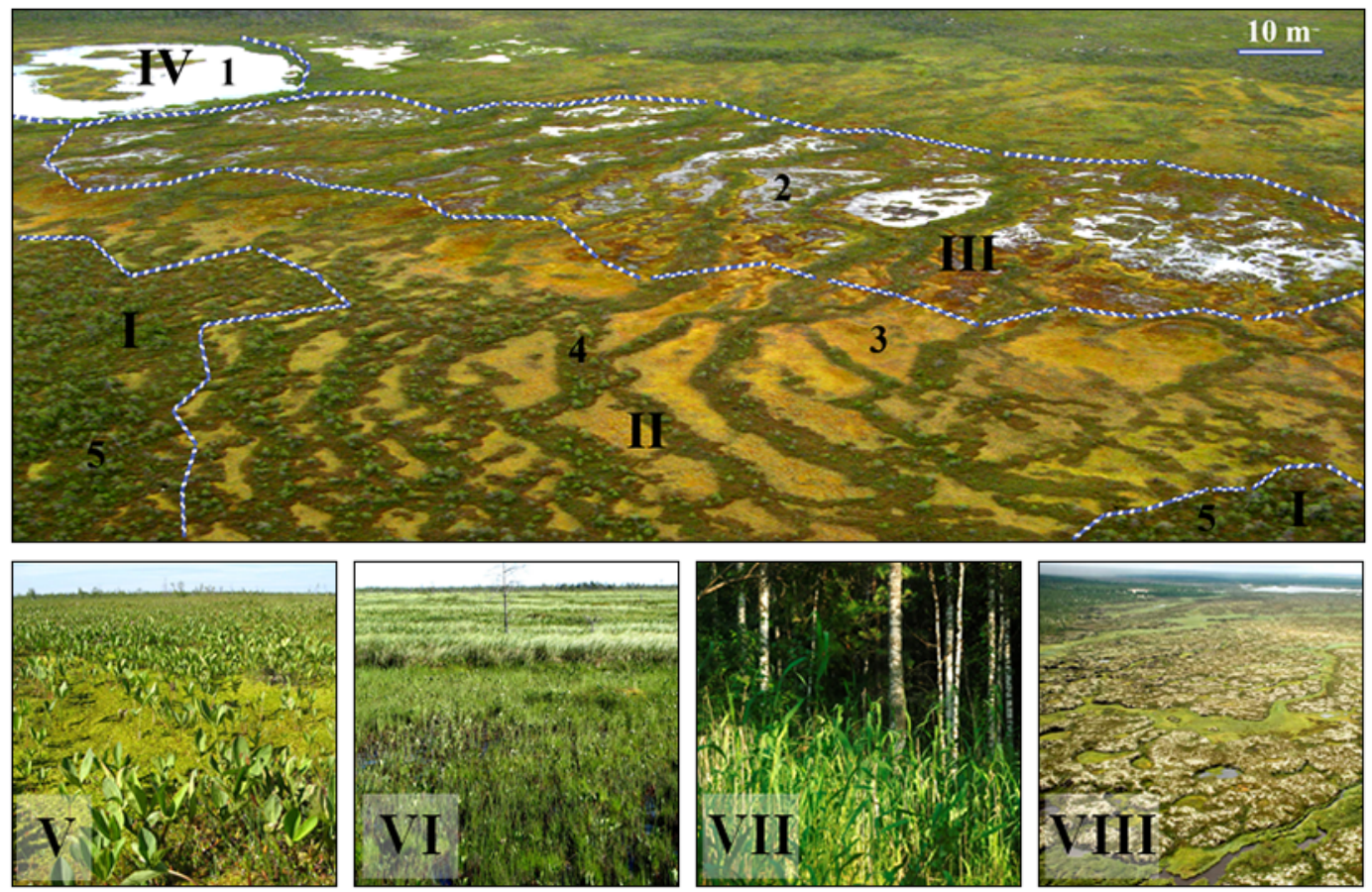

Figure 1. Wetland complexes (I - Pine bog or ryam, II - Ridge-hollow complex or RHC, III - Ridge-hollow-lake complex or RHLC, IV Lakes and rivers, V - Open fens, VI - Patterned fens, VII - Swamps, VIII - Palsa complexes) and ecosystems in WSL (1 - Open water, 2 Waterlogged hollows, 3 - Oligotrophic hollows, 4 - Ridges, 5 - Ryam).

Landsat- 8 was launched after starting our mapping procedure. Finally, we collected 70 suitable scenes during the peak of the growing seasons in different years. Majority of the images were Landsat 5 TM scenes from July 2007. The scene selection procedure was facilitated by the ability of smoothing the slight inconsistencies between images by specifying training sites in overlapping areas.

The overall work flow involves data pre-processing, preparation of the training and test sample collections, image classification on a scene-by-scene basis, regrouping of the derived classes into nine wetland complexes, the estimation of wetland ecosystem fractional coverage and accuracy assessment. Atmospheric correction was not applied because this process is unnecessary as long as the training data are derived from the image being classified (Song et al., 2001). All of the images were re-projected onto the Albers projection. Because the WSL vegetation includes various types of forests, meadows, burned areas, agricultural fields, etc., wetland environments were first separated from other landscapes to avoid misclassification. We used thresholds of the Green-Red Vegetation Index (Motohka et al., 2010) to separate majority of wetlands and forests. Surface water detection was performed using thresholds applied to Landsat's band 5 $(1.55-1.75 \mu \mathrm{m})$. However, because of the vegetation masking effect, detection was limited to open water bodies and inundation not masked by vegetation. Thresholds were empirically determined for each scene by testing various candidate values. Masked Landsat images were filtered in MATLAB v.7.13 (MathWorks) to remove random noise and then classified in Multispec v.3.3 (Purdue Research Foundation) using a supervised classification method. The maximum likelihood algorithm was used because of its robustness and availability in almost any image-processing software (Lu and Weng, 2007). All Landsat bands except the thermal infrared band were used.

Training data play a critical role in the supervised classification technique. Representative data preparation is the most time-consuming and labor-intensive process in regional scale mapping efforts (Gong et al., 2013). As a primary source of information, we used the extensive data set of botanical descriptions, photos, $\mathrm{pH}$ and electrical conductivity data from 28 test sites in WSL (Glagolev et al., 2011). Due to vast expanse and remoteness of WSL, we still had a lack of the ground truth information, which hampered training data set construction. As a result, we had to rely mostly on the high-resolution images available from Google Earth. They came from several satellites (QuickBird, WorldView, GeoEye, IKONOS) with different sensor characteristics; multispectral images were reduced to visible bands (blue, green, red) and had spatial resolution of $1-3 \mathrm{~m}$. The processing started with mapping scenes where ground truth data and high-resolution images are extensively available, so the classification results could be checked for quality assurance; 
Table 1. Wetland ecosystem types.

\begin{tabular}{|c|c|c|}
\hline Wetland ecosystem & Short description & $\begin{array}{l}\text { WTL, cm } \\
(1 \mathrm{st} / 2 \mathrm{nd} / 3 \text { rd quartiles })^{*}\end{array}$ \\
\hline Open water & All water bodies greater than $2 \times 2$ Landsat pixels & - \\
\hline $\begin{array}{l}\text { Waterlogged } \\
\text { hollows }\end{array}$ & $\begin{array}{l}\text { Open water bodies fewer than } 2 \times 2 \text { Landsat pixels or depressed } \\
\text { parts of wetland complexes with WTLs above the average moss/vegetation surface }\end{array}$ & $-10 /-7 /-4$ \\
\hline $\begin{array}{l}\text { Oligotrophic } \\
\text { hollows }\end{array}$ & $\begin{array}{l}\text { Depressed parts of bogs with WTLs beneath the average moss/vegetation cover } \\
\text { beneath the average moss/vegetation cover }\end{array}$ & $3 / 5 / 10$ \\
\hline Ridges & $\begin{array}{l}\text { Long and narrow elevated parts of wetland } \\
\text { complexes with dwarf shrubs-sphagnum vegetation cover }\end{array}$ & $20 / 32 / 45$ \\
\hline Ryams & Extensive pine-dwarf shrubs-sphagnum areas & $23 / 38 / 45$ \\
\hline Fens & $\begin{array}{l}\text { Integrated class for various types of rich fens, poor fens and wooded swamps } \\
\text { f rich fens, poor fens and wooded swamps }\end{array}$ & $7 / 10 / 20$ \\
\hline Palsa hillocks & $\begin{array}{l}\text { Elevated parts of palsa complexes with permafrost below the surface } \\
\text { with permafrost below the surface }\end{array}$ & Less than 45 \\
\hline
\end{tabular}

* Positive WTL means that water is below average moss/soil surface; the data were taken from field data set (Glagolev et al., 2011).

mapping continued through adjacent images and ended at the less explored scenes with poor ground truth data coverage.

To collect training data most efficiently, we used criteria similar to those used by (Gong et al., 2013) for training sample selection, (i) the training samples must be homogeneous; mixed land-cover and heterogeneous areas are avoided; and (ii) all of the samples must be at least 10 pixels in size with an average sample area of approximately 100-200 pixels. The Bhattacharyya distance was used as a class separability measure. However, the classifier was designed using training samples and then evaluated by classifying input data. The percentage of misclassified samples was taken as an optimistic predication of classification performance (Jain et al., 2000). When accuracy of more than $80 \%$ across the training set was attained with no fields showing unreasonable or unexplainable errors, the classification process was started. Classification mismatch between scenes was minimized by placing training samples in overlapping areas. Combining the classified images and area calculations were made using GRASS module in Quantum GIS. Noise filter was applied to eliminate objects smaller than $2 \times 2$ pixels. After that, a $10 \times 10$-pixel moving window was used to determine the dominant class, which was further assigned to the central $4 \times 4$-pixel area.

\subsection{Wetland typology development}

As a starting point for the mapping procedure, a proper classification scheme is required. Congalton et al. (2014) showed that the classification scheme alone may result in largest error contribution and thus deserves highest implementation priority. Its development should rely on the study purposes and the class separability of the input variables. In our case, wetland mapping was initially conceived as a technique to improve the estimate of the regional $\mathrm{CH}_{4}$ emissions and, secondarily, as a base to upscale other ecological functions. WSL wet- lands are highly heterogeneous, however, within each wetland complex we can detect relatively homogeneous structural elements or "wetland ecosystems" with similar water table levels (WTL), geochemical conditions, vegetation covers and, thus, rates of $\mathrm{CH}_{4}$ emissions (Sabrekov et al., 2013). To ensure a reliable upscaling, we assigned seven wetland ecosystems in our classification scheme (Fig. 1; Table 1).

The wetland ecosystems generally have sizes from a few to hundreds of meters and cannot be directly distinguished using Landsat imagery with $30 \mathrm{~m}$ resolutions. Therefore, we developed a second wetland typology that involves 9 mixed "wetland complexes" composing wetland ecosystems in different proportions (Fig. 1; Table 2). The classification was adapted from numerous national studies (Katz and Neishtadt, 1963; Romanova, 1985; Liss et al., 2001; Lapshina, 2004; Solomeshch, 2005; Usova, 2009; Masing et al., 2010) and encompassed wooded, patterned, open wetlands and water bodies. The criteria for assigning wetland complexes were the following: (i) separability on Landsat images, and (ii) abundance in the WSL taiga zone. Each wetland complex represents integral class containing several subtypes differing in vegetation composition and structure. Subtypes were mapped using Landsat images and then generalized into final nine wetland complexes based on ecosystem similarity and spectral separability.

To merge typologies, we estimated relative areas of wetland ecosystems within each wetland complex of the final map. Depending on heterogeneity, 8 to 27 test sites of $0.1-$ $1 \mathrm{~km}^{2}$ size were selected for each heterogeneous wetland complex. High-resolution images of $1-3 \mathrm{~m}$ resolution corresponding to these areas were classified in Multispec v.3.3 using visible channels. An unsupervised ISODATA classification was done on the images specifying 20 classes with a convergence of $95 \%$. Obtained classes were manually reduced to seven wetland ecosystem types. Their relative proportions were calculated and then averaged among the test 
Table 2. Wetland types and fractional coverage of wetland ecosystems (Open water - W, Waterlogged hollows - WH, Oligotrophic hollows - OH, Ridges - R, Ryams - Ry, Fens - F, Palsa hillocks - P).

\begin{tabular}{|c|c|c|}
\hline Wetland complexes & Short description & $\begin{array}{l}\text { Wetland } \\
\text { ecosys- } \\
\text { tems }\end{array}$ \\
\hline \multicolumn{3}{|c|}{ Wooded wetlands } \\
\hline $\begin{array}{l}\text { Pine-dwarf shrubs- } \\
\text { sphagnum bogs (pine } \\
\text { bogs, ryams) }\end{array}$ & $\begin{array}{l}\text { Dwarf shrubs-sphagnum communities with pine trees (local name - "ryams") oc- } \\
\text { cupy the most drained parts of wetlands. Pine height and crown density are posi- } \\
\text { tively correlated with the slope angle. Ryams purely depend on precipitation and } \\
\text { the atmospheric input of nutrients. The next evolutionary type under increased pre- } \\
\text { cipitation is RHC. }\end{array}$ & Ry: $100 \%$ \\
\hline Wooded swamps & $\begin{array}{l}\text { Wooded swamps develop in areas with close occurrence of groundwater. They fre- } \\
\text { quently surround wetland systems; they can also be found in river valleys and } \\
\text { terraces. Wooded swamps are extremely diverse in floristic composition and have } \\
\text { prominent microtopography. }\end{array}$ & F: $100 \%$ \\
\hline \multicolumn{3}{|c|}{ Patterned wetlands } \\
\hline $\begin{array}{l}\text { Ridge-hollow } \\
\text { complexes (RHC) }\end{array}$ & $\begin{array}{l}\text { RHC consists of alternating long narrow ridges and oligotrophic hollows. They } \\
\text { purely depend on precipitation and the atmospheric input of nutrients. The configu- } \\
\text { ration of ridges and hollows depend on the slope angle and hydrological conditions } \\
\text { of the contiguous areas. RHCs with small, medium, and large hollows can be ar- } \\
\text { ranged within the class. }\end{array}$ & $\begin{array}{l}\mathrm{R}: 42 \% \\
\mathrm{OH}: 58 \%\end{array}$ \\
\hline $\begin{array}{l}\text { Ridge-hollow-lake } \\
\text { complexes (RHLC) }\end{array}$ & $\begin{array}{l}\text { RHLCs develop on poorly drained watersheds or after seasonal flooding of pat- } \\
\text { terned wetlands. RHLCs are the most abundant in northern taiga. They may include } \\
\text { numerous shallow pools. Hollows can be both oligotrophic and meso- or eutrophic. }\end{array}$ & $\begin{array}{l}\text { R: } 31 \% \\
\text { OH: } 25 \% \\
\text { WH: } 31 \% \\
\text { F: } 13 \%\end{array}$ \\
\hline Patterned fens & $\begin{array}{l}\text { Patterned fens are widely distributed within the region. They correspond to the WSL } \\
\text { type of aapa mires. Patterned fens are composed of meso- or eutrophic hollows al- } \\
\text { ternating with narrow ridges. The vegetation cover commonly includes sedge-moss } \\
\text { communities. }\end{array}$ & $\begin{array}{l}\mathrm{R}: 28 \% \\
\mathrm{~F}: 72 \%\end{array}$ \\
\hline Palsa complexes & $\begin{array}{l}\text { Palsa complexes are patterned bogs with the presence of palsa hillocks - frost heaves } \\
\text { of } 0.5-1 \text { height. They arise in the north taiga and prevail northwards. They may } \\
\text { include numerous shallow pools. }\end{array}$ & $\begin{array}{l}\text { WH: } 12 \% \\
\text { OH: } 37 \% \\
\text { P: } 51 \%\end{array}$ \\
\hline \multicolumn{3}{|c|}{ Open wetlands } \\
\hline Open bogs & $\begin{array}{l}\text { Open bogs are widespread at the periphery of wetland systems. They are character- } \\
\text { ized by presence of dwarf shrubs-sphagnum hummocks up to } 30 \mathrm{~cm} \text { in height and } \\
50-200 \mathrm{~cm} \text { in size. }\end{array}$ & OH: $100 \%$ \\
\hline Open fens & $\begin{array}{l}\text { Open fens are the integral class that encompasses all varieties of open rich and poor } \\
\text { fens in WSL taiga. They occupy areas with higher mineral supplies at the periphery } \\
\text { of wetland systems and along watercourses. The vegetation cover is highly produc- } \\
\text { tive and includes sedges, herbs, hypnum and brown mosses. }\end{array}$ & F: $100 \%$ \\
\hline \multicolumn{3}{|c|}{ Water bodies } \\
\hline Lakes and rivers & $\begin{array}{l}\text { All water bodies larger than } 60 \times 60 \mathrm{~m}^{2} \text {, so they can be directly distinguished by } \\
\text { Landsat images. }\end{array}$ & W: $100 \%$ \\
\hline
\end{tabular}




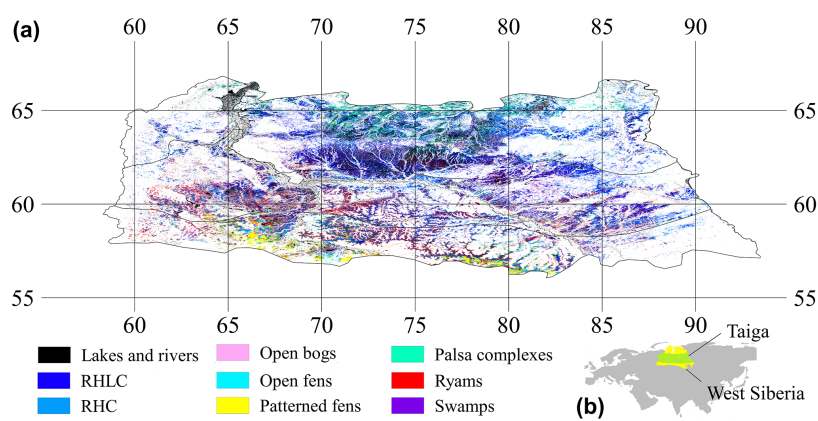

Figure 2. Wetland map (a) of the WSL taiga zone (b; yellow - WS, green - taiga zone).

sites. Thus, we used a multiscale approach relying in two typologies. First, typology of wetland complexes was used for mapping Landsat images; second, typology of wetland ecosystems was used for upscaling $\mathrm{CH}_{4}$ fluxes. The approach is similar to one devised by Peregon et al. (2005), where relative area proportions of "micro-landscape" elements within SHI wetland map were used for NPP data upscaling.

During wetland typology development, we made several assumptions; (i) the wetland complexes were considered as individual objects, while they actually occupy a continuum with no clustering into discrete units. (ii) All of the wetland water bodies originated during wetland development have sizes less than $2 \times 2$ Landsat pixels. They are represented by wetland pools and waterlogged hollows, which are structural components of ridge-hollow-lake complexes (RHLC). The rest of the water bodies were placed into the "Lakes and rivers" class. (iii) in this study, we only consider peatlands and water bodies; floodplain areas were separated from wetlands during the classification process.

The concept of wetland ecosystems has merits on $\mathrm{CH}_{4}$ emission inventory. Methane emission from wetland ecosystems depends mainly on water table level, temperature, and trophic state (Dise et al., 1993; Dunfield et al., 1993; Conrad, 1996). The temperature is taken into account, when fluxes are upscaled separately for southern, middle and northern taiga whereas trophic state is significant, when wetland complexes are mapped using multispectral Landsat images. The water table level is considered while mapping vegetation of wetland ecosystems with high-resolution images, because vegetation reflects soil moisture conditions. We do not directly consider smallest spatial elements as hummocks and tussocks. This omission introduces some uncertainty in regional $\mathrm{CH}_{4}$ emission estimate, which was evaluated by Sabrekov et al. (2014). Accordingly, reliable estimate of $\mathrm{CH}_{4}$ fluxes accounting for fine spatial detail requires a large number of measurements. Such heterogeneity is being addressed by measuring fluxes in all microforms in the field and then obtaining probability density distributions.

\section{Results and discussion}

\subsection{Wetland map}

Based on Landsat imagery, we developed a high-resolution wetland inventory of the WSL taiga zone (Fig. 2). The total area of wetlands and water bodies was estimated to be 52.4 Mha. West Siberian taiga wetlands are noticeable even from a global perspective. The global total of inundated areas and peatlands was estimated to cover from 430 (Cogley, 1994) to 1170 Mha (Lehner and Döll, 2004) as summarized by Melton et al. (2013); therefore, taiga wetlands in WSL account for approximately from 4 to $12 \%$ of the global wetland area. Their area is larger than the wetland areas of 32.4, 32, and 41 Mha in China (Niu et al., 2012), Hudson Bay Lowland (Cowell, 1982) and Alaska (Whitcomb et al., 2009), respectively. The extent of West Siberia's wetlands exceeds the tropical wetland area of 43.9 Mha (Page et al., 2011) emphasizing the considerable ecological role of the study region.

As summarized by Sheng et al. (2004), the majority of earlier Russian studies estimated the extent of the entire WS's mires to be considerably lower. These studies probably inherited the drawbacks of the original Russian Federation Geological Survey database, which was used as the basis for the existing WSL peatland inventories (Ivanov and Novikov, 1976). This database suffered from lack of field survey data in remote regions, a high generalization level and economically valuable peatlands with peat layers deeper than $50 \mathrm{~cm}$ were only considered.

Our peatland coverage is similar to the estimate of 51.5 Mha (Peregon et al., 2009) by SHI map (Romanova et al., 1977). However, a direct comparison between the peatland maps shows that the SHI map is missing important details on the wetland distribution (Fig. 3). SHI map was based on aerial photography, which was not technically viable for full and continuous mapping of a whole region because it is not cost effective and time-consuming to process (Adam et al., 2009).

Distribution of wetland ecosystem areas have changed significantly in comparison to SHI map (Peregon et al., 2009); in particular, we obtained a $105 \%$ increase in the spatial extent of $\mathrm{CH}_{4}$ high-emitting ecosystems such as waterlogged, oligotrophic hollows and fens. In the case study of WS's middle taiga, we found that applying the new wetland map led to a $130 \%$ increase in the $\mathrm{CH}_{4}$ flux estimate from the domain (Kleptsova et al., 2012) in comparison with the estimate based on SHI map. Thus, a considerable revaluation of the total $\mathrm{CH}_{4}$ emissions from the whole region is expected.

\subsection{Regularities of zonal distribution}

WS has a large variety of wetlands that developed under different climatic and geomorphologic conditions. Concerning the wetland complex typology (excluding "Lakes and rivers" class), ridge-hollow complexes (RHC) prevail in WS's taiga, 
Table 3. Latitudinal distribution of wetland ecosystem types.

\begin{tabular}{lrrrrrrrr}
\hline \multirow{2}{*}{ Wetland ecosystem } & \multicolumn{2}{c}{ South taiga } & \multicolumn{3}{c}{ Middle taiga } & \multicolumn{2}{c}{ North taiga } & \multicolumn{2}{c}{ Total area } \\
\cline { 2 - 9 } types & Area, Mha & $\%$ & Area, Mha & $\%$ & Area, Mha & $\%$ & Area, Mha & $\%$ \\
\hline Open water & 0.37 & 3 & 1.66 & 9 & 3.91 & 19 & 5.94 & 11.3 \\
Waterlogged hollows & 0.50 & 4 & 1.32 & 7 & 3.40 & 16 & 5.22 & 10.0 \\
Oligotrophic hollows & 1.87 & 16 & 5.78 & 30 & 5.60 & 27 & 13.25 & 25.3 \\
Ridges & 1.70 & 14 & 3.61 & 19 & 3.37 & 16 & 8.69 & 16.6 \\
Ryams & 3.37 & 28 & 5.14 & 27 & 1.60 & 8 & 10.11 & 19.3 \\
Fens & 4.22 & 35 & 1.77 & 9 & 1.53 & 7 & 7.52 & 14.3 \\
Palsa hillocks & 0.00 & 0 & 0.00 & 0 & 1.71 & 8 & 1.71 & 3.3 \\
\hline Total wetland area & 12.04 & & 19.27 & & 21.13 & 52.44 \\
Total zonal area & 42.96 & 56.56 & & 58.46 & 36.1 & 157.97 \\
Paludification, $\%$ & 28.0 & & 34.1 & & 33.2 \\
\hline
\end{tabular}
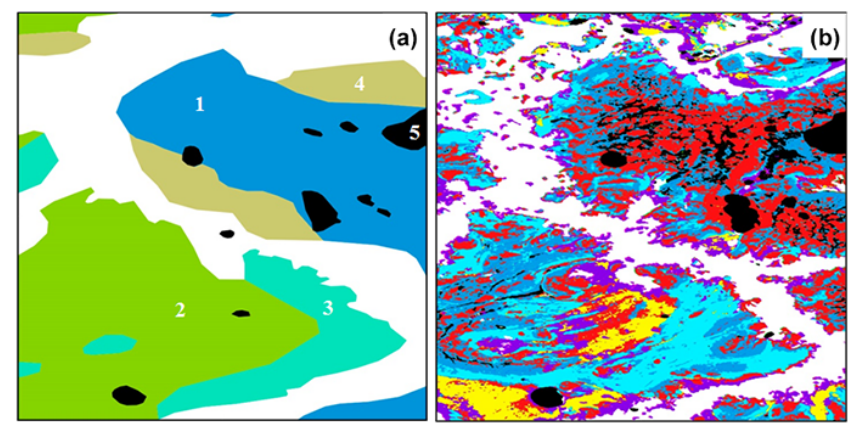

Figure 3. Comparison of wetland classifications: (a) SHI map (1 - Sphagnum-dominated bogs with pools and open stand of trees, 2 - ridge-hollow, ridge-hollow-pool and ridge-pool patterned bogs, 3 - forested shrubs- and moss-dominated mires, 4 - moss-dominated treed mires, 5 - water bodies), (b) present study (legend same as in Fig. 2); $59-59.5^{\circ} \mathrm{N}, 66-66.5^{\circ} \mathrm{E}$.

accounting for $32.2 \%$ of the total wetland area, followed by pine bogs $(23 \%)$, RHLCs $(16.4 \%)$, open fens $(8.4 \%)$, palsa complexes $(7.6 \%)$, open bogs $(4.8 \%)$, patterned fens (3.9\%) and swamps $(3.7 \%)$. Various bogs are dominant among the wetland ecosystems (Table 3 ), while fens cover only $14.3 \%$ of the wetlands. Waterlogged hollows and open water occupy $7 \%$ of the region, which is similar to the estimate by Watts et al. (2014), who found that $5 \%$ of the boreal-Arctic domain was inundated during summer season.

The individual wetland environments have a pronounced latitudinal zonality within the study region. Zonal borders stretch closely along latitude lines, subdividing the taiga domain into the southern, middle, and northern taiga subzones (Fig. 2, black lines). To visualize the regularities of the wetland distribution, we divided the entire area into $0.1^{\circ} \times 0.1^{\circ}$ grids and calculated ratios of wetland ecosystem areas to the total cell areas for each grid (Fig. 4) using fractional coverage data from Table 2.
Mire coverage of WSL's northern taiga $\left(62-65^{\circ} \mathrm{N}\right)$ is approximately $36 \%$. Because of the abundance of precipitation, low evaporation and slow runoff, the northern taiga is characterized by largest relative area of lakes and waterlogged hollows, covering a third of the domain (Fig. 4a, b). Vast parts of the zone are occupied by the peatland system "Surgutskoe Polesye," which stretches for $100 \mathrm{~km}$ from east to west between 61.5 and $63^{\circ} \mathrm{N}$. Peatland and water bodies cover up to $70 \%$ of the territory, forming several huge peatland-lake complexes divided by river valleys. Northward, the slightly paludified "Siberian Uvaly" elevation $\left(63.5^{\circ} \mathrm{N}\right)$ divides the northern taiga into two lowland parts. Palsa hillocks appear in the "Surgutskoe Polesye" region and replace the ridges and ryams to the north of the "Siberian Uvaly" region (Fig. 4f).

RHCs are the most abundant in the middle taiga (59$62^{\circ} \mathrm{N}$ ), where mires occupy $34 \%$ of the area, whereas large wetland systems in this region commonly cover watersheds and have a convex dome with centers of 3-6 $\mathrm{m}$ higher than periphery. These environments have peat layer of several meters depth composed of sphagnum peat with the small addition of other plants. Also, the wetland ecosystems present here have distinct spatial regularities. Central plateau depressions with stagnant water are covered by RHLCs. Different types of RHCs cover better-drained gentle slopes. The most drained areas are dominated by ryams. Poor and rich fens develop along wetland's edges with relatively high nutrient availability. Wooded swamps usually surround vast wetland systems.

The wetland extent reaches $28 \%$ in WS's southern taiga area $\left(56-59^{\circ} \mathrm{N}\right)$. Wetlands are composed of raised bogs alternating with huge open and patterned fens. The eastern part of the subzone is dominated by small and medium-sized wetland complexes. The southern and middle taiga wetlands exhibit similar spatial patterns; however, the area of fens increases southward due to the abundance of carbonate soils and higher nutrient availability. Velichko et al. (2011) provide evidence for existence of a vast cold desert in the north- 

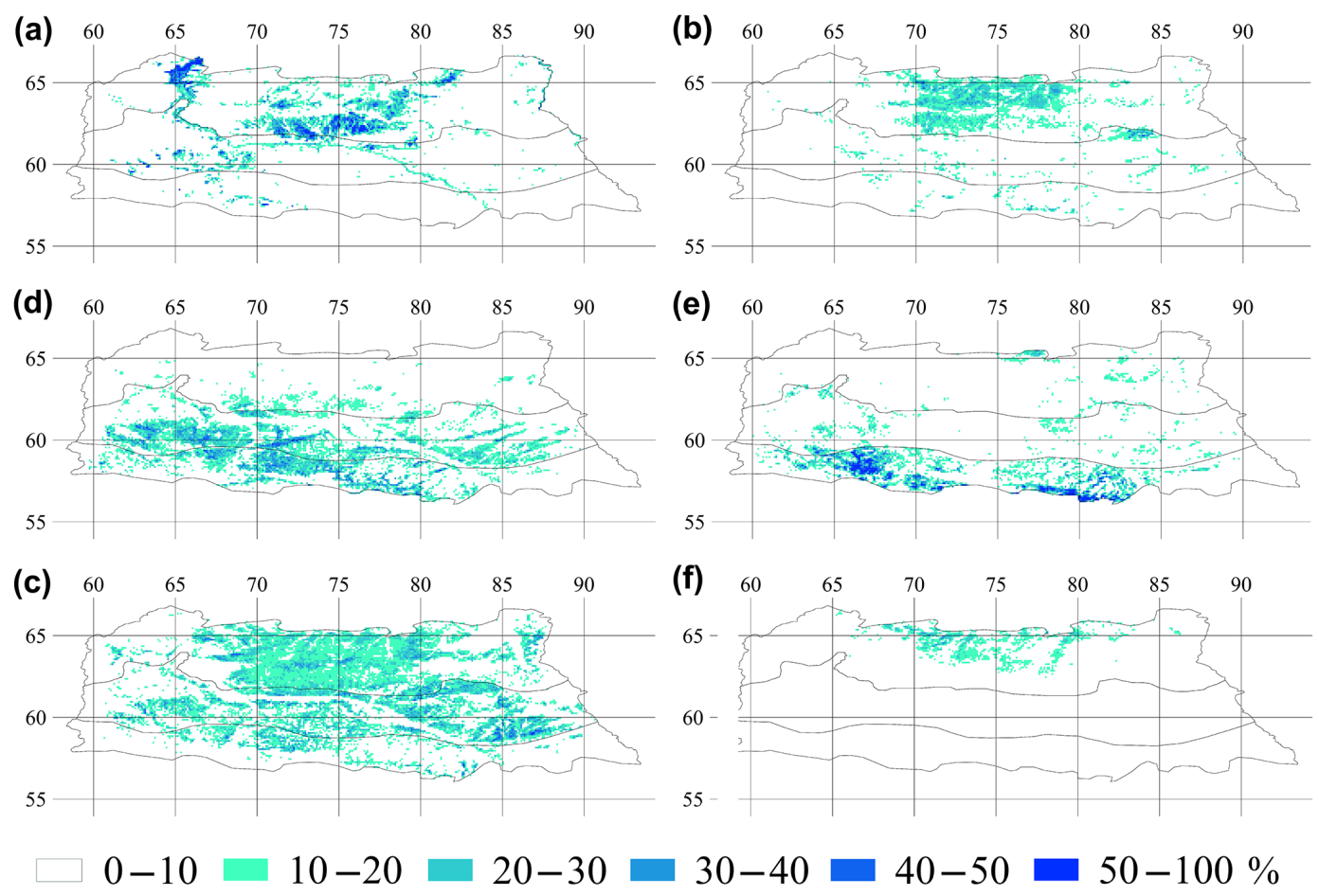

Figure 4. Wetland ecosystem areas for $0.1^{\circ} \times 0.1^{\circ}$ (\% from the total cell area): (a) open water, (b) waterlogged hollows, (c) oligotrophic hollows, (d) ryams, (e) fens, (f) palsa hillocks; the distribution of ridges is not represented because it is quite similar to the oligotrophic hollow distribution; the black outlines divide the taiga into the north, middle and south taiga subzones.

ern half of the WSL at the late glacial time, whereas the southernmost part was an area of loess accumulation. The border between fen and bog-dominated areas extends near $59^{\circ} \mathrm{N}$ and corresponds to the border between the southern and middle taiga zones (Fig. $4 \mathrm{c}$ and e).

\subsection{Accuracy assessment}

The map accuracy assessment was based on 1082 validation polygons of $10 \times 10$ pixels that were randomly spread over the WSL taiga zone. We used high-resolution images available on Google Earth as the ground truth information. The confusion matrix (Table 4) was used as a way to represent map accuracy (Congalton and Green, 2008). Overall, we achieved the classification accuracy of $79 \%$ that can be considered reasonable for such a large and remote area. We found that the accuracies for different land-cover categories varied from 62 to $99 \%$, with the lake and river, ryam, and RHC class areas mapped more accurately whereas open bogs and patterned fens are less accurate. Some errors were associated with mixed pixels ( 33 polygons), whose presence had been recognized by Foody (2002) as a major problem, affecting the effective use of remotely sensed data in per-pixel classification.

Wetland complexes within large wetland systems had the highest classification accuracies while the uncertainties are particularly high for small objects. The southern part of the domain is significant with highly heterogeneous agricultural landscapes neighbor upon numerous individual wetlands of 100-1000 ha area. Therefore, several vegetation indices were tested to map them; however, the best threshold was achieved by using Landsat thermal band. In addition, many errors occurred along the tundra boundary due to the lack of ground truth data and high landscape heterogeneity. However, those small areas mainly correspond to palsa complexes and have a negligibly small impact on $\mathrm{CH}_{4}$ flux estimate.

Misclassifications usually occurred between similar classes introducing only a minor distortion in map applications. Patterned fens and open bogs were classified with the lowest producer's accuracy (PA) of $62 \%$. Patterned fens include substantial treeless areas, so they were often misclassified as open fens. They were also confused with RHCs due to the similar "ridge-hollow" structure. Some open bogs have tussock shrub cover with sparsely distributed pine trees leading to misclassification as RHCs and pine bogs. Open fens have higher user's accuracy (UA) and PA; however, visible channels of high-resolution images poorly reflect trophic state, which underrates classification errors between open bogs and open fens. Swamps and palsa complexes have very high PA and low UA, which is related to their inaccurate identification in non-wetland areas. Palsa complexes were spectrally close to open woodlands with lichen layer, which 
Table 4. Confusion matrix of West Siberian wetland map validation (additional 11 floodplain and 33 mixed class polygons classified as wetlands are not presented).

\begin{tabular}{|c|c|c|c|c|c|c|c|c|c|c|c|c|}
\hline 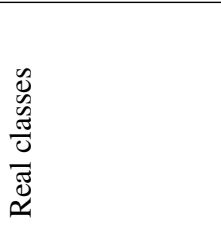 & $\begin{array}{l}\vec{\Xi} \\
\tilde{\Xi} \\
\tilde{\Xi} \\
3 \\
1 \\
0 \\
z \\
z\end{array}$ & 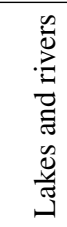 & 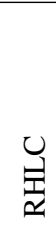 & $\begin{array}{l}\mathscr{0} \\
8 \\
8 \\
. \\
.\end{array}$ & $\underset{\sim}{\stackrel{U}{2}}$ & 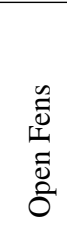 & 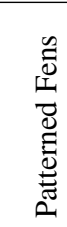 & 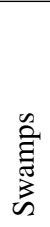 & 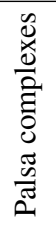 & $\begin{array}{l}0 \\
0 \\
0 \\
8 \\
\tilde{0} \\
\tilde{0} \\
0\end{array}$ & 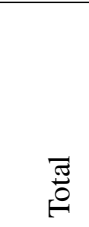 & $\stackrel{\circ}{\overleftarrow{b}}$ \\
\hline \multicolumn{13}{|l|}{$\begin{array}{l}\text { Estimated } \\
\text { classes }\end{array}$} \\
\hline Non-wetland & 110 & & & 1 & & & & & & 2 & 113 & 97 \\
\hline Lakes and rivers & & 94 & 3 & & & & & 1 & & & 98 & 96 \\
\hline RHLC & 4 & 7 & 69 & 1 & 4 & & & & 2 & & 87 & 79 \\
\hline Pine bogs & 3 & & 1 & 108 & 7 & & 4 & & & 7 & 130 & 83 \\
\hline RHC & 1 & & 6 & 2 & 150 & 5 & 9 & & & 8 & 181 & 83 \\
\hline Open Fens & & & 3 & 1 & 3 & 86 & 20 & & & 3 & 116 & 74 \\
\hline Patterned Fens & 1 & & 4 & 1 & & 18 & 68 & & & & 92 & 74 \\
\hline Swamps & 5 & & & & & 4 & 9 & 82 & & & 100 & 82 \\
\hline Palsa complexes & 13 & & 1 & 2 & 1 & & & & 54 & 3 & 74 & 73 \\
\hline Open bogs & & & & 1 & 7 & 1 & & & & 38 & 47 & 81 \\
\hline Total & 137 & 101 & 87 & 117 & 172 & 114 & 110 & 83 & 56 & 61 & 1038 & \\
\hline $\mathrm{PA}^{2} \%$ & 80 & 93 & 79 & 92 & 87 & 75 & 62 & 99 & 96 & 62 & & \\
\hline
\end{tabular}

covers wide areas of WSL north taiga. During dry period, swamps were often confused with forests, whereas in the field they can be easily identified through the presence of peat layers and a characteristic microrelief. In both cases, more accurate wetland masks would lead to substantially higher accuracy levels. Lakes and rivers were well classified due to its high spectral separability. They can be confused with RHLCs represented by a series of small lakes or waterlogged hollows alternating with narrow isthmuses. Floodplains after snowmelt can also be classified as lakes (11 polygons). RHCs and pine bogs were accurately identified due to their abundance in the study region and high spectral separability.

\subsection{Challenges and future prospects}

The contrast between vast wetland systems and the surrounding forests is so distinct in WSL that wetlands can be adequately identified by the summer season images (Sheng et al., 2004). On the contrary, correct mapping of wetland with pronounced seasonal variations remains one of the largest challenges. Wetlands become the most inundated after snowmelt or rainy periods resulting in partial transformation of oligotrophic hollows and fens into waterlogged hollows (see hollows with brown Sphagnum cover at Fig. 1). Image features of swamps after drought periods become similar to forests. Interannual variability of water table level in WSL wetlands (Schroeder et al., 2010; Watts et al., 2014) also makes impact on mapping results.

New methodologies and protocols are needed to improve our ability to monitor water levels (Kim et al., 2009). Ob- servations of soil moisture and wetland dynamic using radar data such as PALSAR (Chapman et al., 2015; Clewley et al., 2015) and Global Navigation Satellite Signals Reflectometry are promising (Chew et al., 2016; Zuffada et al., 2015). In addition, advanced classification techniques such as fuzzy logic can be applied for mapping fine-scale heterogeneity (Adam et al., 2009). Recent innovations in wetland mapping were described by Tiner et al. (2015).

Water table fluctuations are particularly important for upscaling $\mathrm{CH}_{4}$ fluxes because the spatial distribution of methane emissions, and therefore, the total methane emission, are functions of the spatial distribution of water table depths (Bohn et al., 2007). Wetland ecosystems with water levels close to surface contribute most to the regional flux, while the contribution of dryer ecosystems (ryams, ridges and palsa hillocks) is negligible (Glagolev et al., 2011; Sabrekov et al., 2014).

Although the synergistic combination of active and passive microwave sensor data is useful for accurately characterizing open water (Schroeder et al., 2010) and wetlands; the remote sensing of water regimes is successful only when in situ data are available for calibration. We still lack in situ measurements of the water table dynamics within WSL wetlands. Limited monitoring has been made at the Bakchar field station (Krasnov et al., 2013, 2015) and Mukhrino field station (Bleuten and Filippov, 2008); however, the vast majority of obtained data have not yet been analyzed and published. These measurements are of special importance for the northern taiga and tundra, where shallow thermokarst lakes with fluctuating water regimes cover huge areas. 
The scarcity of reliable reference data and subsequent lack of consistency also limit the accuracy of maps (Homer and Gallant, 2001). The use of ancillary data can largely improve it (Congalton et al., 2014); however, more reliable classification accuracy is attainable with detailed field data. Further improvement in mapping is possible with the acquisition of more ground truth data for the poorly classified wetland types and remote regions.

\section{Conclusions}

Boreal peatlands play a major role in carbon storage, methane emissions, water cycling and other global environmental processes, but better understanding of this role is constrained by the inconsistent representation of peatlands on (or even complete omission from) many global land cover maps (Krankina et al., 2008). In this study we developed a map representing the state of the taiga wetlands in WSL during the peak of the growing season. The efforts reported here can be considered as an initial attempt at mapping boreal wetlands using Landsat imagery, with the general goal to support the monitoring of wetland resources and upscaling the methane emissions from wetlands and inland waters. The resulting quantitative definitions of wetland complexes combined with a new wetland map can be used for the estimation and spatial extrapolation of many ecosystem functions from site-level observations to the regional scale. In the case study of WS's middle taiga, we found that applying the new wetland map led to a $130 \%$ increase in the $\mathrm{CH}_{4}$ flux estimation from the domain (Kleptsova et al., 2012) comparing with estimation based on previously used SHI map. Thus, a considerable reevaluation of the total $\mathrm{CH}_{4}$ emissions from the entire region is expected.

We estimate a map accuracy of $79 \%$ for this large and remote area. Further improvement in the mapping quality will depend on the acquisition of ground truth data from the least discernible wetland landscapes and remote regions. Moreover, distinguishing wetland complexes with strong seasonal variability in their water regimes remains one of the largest challenges. This difficulty can be resolved by installing water level gauge network and usage of both remote sensing data and advanced classification techniques.

Our new Landsat-based map of WS's taiga wetlands can be used as a benchmark data set for validation of coarseresolution global land cover products and for assessment of global model performance in high latitudes. Although classification scheme was directed towards improving $\mathrm{CH}_{4}$ inventory, the resulting map can also be applied for upscaling of the other environmental parameters.

\section{The Supplement related to this article is available online} at doi:10.5194/bg-13-4615-2016-supplement.
Acknowledgements. We thank Amber Soja and anonymous reviewers for assisting in improving the initial version of the manuscript. This study (research grant no 8.1.94.2015) was supported by The Tomsk State University Academic D.I. Mendeleev Fund Program in 2014-2015. The study was also supported by the GRENE-Arctic project by MEXT Japan.

Edited by: P. Stoy

Reviewed by: three anonymous referees

\section{References}

Adam, E., Mutanga, O., and Rugege, D.: Multispectral and hyperspectral remote sensing for identification and mapping of wetland vegetation: a review, Wetl. Ecol. Manag., 18, 281-296, doi:10.1007/s11273-009-9169-z, 2009.

Bleuten, W. and Filippov, I.: Hydrology of mire ecosystems in central West Siberia: the Mukhrino Field Station, Transactions of UNESCO department of Yugorsky State University "Dynamics of environment and global climate change"/Glagolev MV, edited by: Lapshina, E. D., Novosibirsk: NSU, 208-224, 2008.

Bohn, T. J., Lettenmaier, D. P., Sathulur, K., Bowling, L. C., Podest, E., McDonald, K. C., and Friborg, T.: Methane emissions from western Siberian wetlands: heterogeneity and sensitivity to climate change, Environ. Res. Lett., 2, 045015, doi:10.1088/17489326/2/4/045015, 2007.

Bohn, T. J., Melton, J. R., Ito, A., Kleinen, T., Spahni, R., Stocker, B. D., Zhang, B., Zhu, X., Schroeder, R., Glagolev, M. V., Maksyutov, S., Brovkin, V., Chen, G., Denisov, S. N., Eliseev, A. V., Gallego-Sala, A., McDonald, K. C., Rawlins, M. A., Riley, W. J., Subin, Z. M., Tian, H., Zhuang, Q., and Kaplan, J. O.: WETCHIMP-WSL: intercomparison of wetland methane emissions models over West Siberia, Biogeosciences, 12, 3321-3349, doi:10.5194/bg-12-3321-2015, 2015.

Chapman, B., McDonald, K., Shimada, M., Rosenqvist, A., Schroeder, R., and Hess, L.: Mapping regional inundation with spaceborne L-band SAR, Remote Sensing, 7, 5440-5470, 2015.

Chew, C., Shah, R., Zuffada, C., Hajj, G., Masters, D., and Mannucci, A. J.: Demonstrating soil moisture remote sensing with observations from the UK TechDemoSat1 satellite mission, Geophys. Res. Lett., 43, 3317-3324, 2016.

Clewley, D., Whitcomb, J., Moghaddam, M., McDonald, K., Chapman, B., and Bunting, P.: Evaluation of ALOS PALSAR data for high-resolution mapping of vegetated wetlands in Alaska, Remote Sensing, 7, 7272-7297, 2015.

Cogley, J.: GGHYDRO: global hydrographic data, Peterborough, Ontario, Canada, 1994.

Congalton, R., Gu, J., Yadav, K., Thenkabail, P., and Ozdogan, M.: Global Land Cover Mapping: A Review and Uncertainty Analysis, Remote Sensing, 6, 12070-12093, doi:10.3390/rs61212070, 2014.

Congalton, R. G. and Green, K.: Assessing the accuracy of remotely sensed data: principles and practices, CRC press, Florida, USA, 2008.

Conrad, R.: Soil microorganisms as controllers of atmospheric trace gases $\left(\mathrm{H}_{2}, \mathrm{CO}, \mathrm{CH}_{4}, \mathrm{OCS}, \mathrm{N}_{2} \mathrm{O}\right.$, and $\left.\mathrm{NO}\right)$, Microbiol. Rev., 60, 609-640, 1996. 
Cowell, D. W.: Earth Sciences of the Hudson Bay Lowland: Literature Review and Annotated Bibliography, Lands Directorate, Environment Canada, 1982.

Dise, N. B., Gorham, E., and Verry, E. S.: Environmental factors controlling methane emissions from peatlands in northern Minnesota, J. Geophys. Res.-Atmos., 98, 10583-10594, 1993.

Dunfield, P., Dumont, R., and Moore, T. R.: Methane production and consumption in temperate and subarctic peat soils: response to temperature and pH, Soil Biol. Biochem., 25, 321-326, 1993.

Foody, G. M.: Status of land cover classification accuracy assessment, Remote Sens. Environ., 80, 185-201, 2002.

Frey, K. E. and Smith, L. C.: How well do we know northern land cover? Comparison of four global vegetation and wetland products with a new ground-truth database for West Siberia, Global Biogeochem. Cy., 21, GB1016, doi:10.1029/2006gb002706, 2007.

Giri, C., Ochieng, E., Tieszen, L. L., Zhu, Z., Singh, A., Loveland, T., Masek, J., and Duke, N.: Status and distribution of mangrove forests of the world using earth observation satellite data, Global Ecol. Biogeogr., 20, 154-159, doi:10.1111/j.14668238.2010.00584.x, 2011.

Glagolev, M., Kleptsova, I., Filippov, I., Maksyutov, S., and Machida, T.: Regional methane emission from West Siberia mire landscapes, Environ. Res. Lett., 6, 045214, doi:10.1088/17489326/6/4/045214, 2011.

Gong, P., Wang, J., Yu, L., Zhao, Y., Zhao, Y., Liang, L., Niu, Z., Huang, X., Fu, H., Liu, S., Li, C., Li, X., Fu, W., Liu, C., Xu, Y., Wang, X., Cheng, Q., Hu, L., Yao, W., Zhang, H., Zhu, P., Zhao, Z., Zhang, H., Zheng, Y., Ji, L., Zhang, Y., Chen, H., Yan, A., Guo, J., Yu, L., Wang, L., Liu, X., Shi, T., Zhu, M., Chen, Y., Yang, G., Tang, P., Xu, B., Giri, C., Clinton, N., Zhu, Z., Chen, J., and Chen, J.: Finer resolution observation and monitoring of global land cover: first mapping results with Landsat TM and ETM+ data, Int. J. Remote Sens., 34, 2607-2654, doi:10.1080/01431161.2012.748992, 2013.

Gvozdetsky, N.: Physiographic zoning of USSR, MSU, Moscow, Russia, 576 pp., 1968.

Homer, C. and Gallant, A.: Partitioning the conterminous United States into mapping zones for Landsat TM land cover mapping, Unpublished US Geologic Survey report, 2001.

Ivanov, K. and Novikov, S.: West Siberian peatlands, their structure and hydrological regime, Gidrometeoizdat, Leningrad, USSR, 448 pp., 1976.

Jain, A. K., Duin, R. P., and Mao, J.: Statistical pattern recognition: A review, IEEE T. Pattern Anal., 22, 4-37, 2000.

Jones, L. A., Ferguson, C. R., Kimball, J. S., Zhang, K., Chan, S. T. K., McDonald, K. C., Njoku, E. G., and Wood, E. F.: Satellite microwave remote sensing of daily land surface air temperature minima and maxima from AMSR-E, IEEE J. Sel. Top. Appl., 3, 111-123, 2010.

Katz, N. and Neishtadt, M.: Peatlands, in: West Siberia, edited by: Rihter, G. D., AS USSR, Moscow, Russia, 230-248, 1963.

Kim, J.-W., Lu, Z., Lee, H., Shum, C. K., Swarzenski, C. M., Doyle, T. W., and Baek, S.-H.: Integrated analysis of PALSAR/Radarsat1 InSAR and ENVISAT altimeter data for mapping of absolute water level changes in Louisiana wetlands, Remote Sens. Environ., 113, 2356-2365, doi:10.1016/j.rse.2009.06.014, 2009.

Kleptsova, I., Glagolev, M., Lapshina, E., and Maksyutov, S.: Landcover classification of the Great Vasyugan mire for estimation of methane emission, in: 1st International Conference on "Global Warming and the Human-Nature Dimension in Siberia: Social Adaptation to the Changes of the Terrestrial Ecosystem, with an Emphasis on Water Environments" (7-9 March 2012, Kyoto, Japan), 2012.

Krankina, O. N., Pflugmacher, D., Friedl, M., Cohen, W. B., Nelson, P., and Baccini, A.: Meeting the challenge of mapping peatlands with remotely sensed data, Biogeosciences, 5, 1809-1820, doi:10.5194/bg-5-1809-2008, 2008.

Krasnov, O. A., Maksutov, S. S., Glagolev, M. V., Kataev, M. Y., Inoue, G., Nadeev, A. I., and Schelevoi, V. D.: Automated complex "Flux-NIES" for measurement of methane and carbon dioxide fluxes, Atmos. Ocean. Opt., 26, 1090-1097, 2013.

Krasnov, O. A., Maksyutov, S. S., Davydov, D. K., Fofonov, A. V., and Glagolev, M. V.: Measurements of methane and carbon dioxide fluxes on the Bakchar bog in warm season, in: XXI International Symposium Atmospheric and Ocean Optics, Atmospheric Physics, 968066-968066-968064, International Society for Optics and Photonics, 2015.

Kremenetski, K. V., Velichko, A. A., Borisova, O. K., MacDonald, G. M., Smith, L. C., Frey, K. E., and Orlova, L. A.: Peatlands of the Western Siberian lowlands: current knowledge on zonation, carbon content and Late Quaternary history, Quaternary Sci. Rev., 22, 703-723, doi:10.1016/s0277-3791(02)00196-8, 2003.

Lapshina, E.: Peatland vegetation of south-east West Siberia, TSU, Tomsk, Russia, 296 pp., 2004.

Lehner, B. and Döll, P.: Development and validation of a global database of lakes, reservoirs and wetlands, J. Hydrol., 296, 1-22, doi:10.1016/j.jhydrol.2004.03.028, 2004.

Liss, O., Abramova, L., Avetov, N., Berezina, N., Inisheva, L., Kurnishkova, T., Sluka, Z., Tolpysheva, T., and Shvedchikova, N.: Mire systems of West Siberia and its nature conservation importance, Grif and Co, Tula, Russia, 584 pp., 2001.

Lu, D. and Weng, Q.: A survey of image classification methods and techniques for improving classification performance, Int. J. Remote Sens., 28, 823-870, doi:10.1080/01431160600746456, 2007.

Masing, V., Botch, M., and Läänelaid, A.: Mires of the former Soviet Union, Wetl. Ecol. Manag., 18, 397-433, 2010.

Matthews, E. and Fung, I.: Methane emission from natural wetlands: Global distribution, area, and environmental characteristics of sources, Global Biogeochem. Cy., 1, 61-86, 1987.

Melton, J. R., Wania, R., Hodson, E. L., Poulter, B., Ringeval, B., Spahni, R., Bohn, T., Avis, C. A., Beerling, D. J., Chen, G., Eliseev, A. V., Denisov, S. N., Hopcroft, P. O., Lettenmaier, D. P., Riley, W. J., Singarayer, J. S., Subin, Z. M., Tian, H., Zürcher, S., Brovkin, V., van Bodegom, P. M., Kleinen, T., Yu, Z. C., and Kaplan, J. O.: Present state of global wetland extent and wetland methane modelling: conclusions from a model intercomparison project (WETCHIMP), Biogeosciences, 10, 753788, doi:10.5194/bg-10-753-2013, 2013.

Motohka, T., Nasahara, K. N., Oguma, H., and Tsuchida, S.: Applicability of green-red vegetation index for remote sensing of vegetation phenology, Remote Sensing, 2, 2369-2387, 2010.

National Atlas of Russia: Environment (Nature), Ecology, http: //xn--80aaaa1bhnclcci1cl5c4ep.xn--p1ai/cd2/english.html (last access: 28 March 2016), 2008.

Niu, Z., Zhang, H., Wang, X., Yao, W., Zhou, D., Zhao, K., Zhao, H., Li, N., Huang, H., Li, C., Yang, J., Liu, C., Liu, S., Wang, L., 
Li, Z., Yang, Z., Qiao, F., Zheng, Y., Chen, Y., Sheng, Y., Gao, X., Zhu, W., Wang, W., Wang, H., Weng, Y., Zhuang, D., Liu, J., Luo, Z., Cheng, X., Guo, Z., and Gong, P.: Mapping wetland changes in China between 1978 and 2008, Chinese Sci. Bull., 57, 2813-2823, doi:10.1007/s11434-012-5093-3, 2012.

Page, S. E., Rieley, J. O., and Banks, C. J.: Global and regional importance of the tropical peatland carbon pool, Glob. Change Biol., 17, 798-818, 2011.

Papa, F., Prigent, C., Aires, F., Jimenez, C., Rossow, W. B., and Matthews, E.: Interannual variability of surface water extent at the global scale, 1993-2004, J. Geophys. Res., 115, D12111, doi:10.1029/2009jd012674, 2010.

Peregon, A., Maksyutov, S., Kosykh, N., Mironycheva-Tokareva, N., Tamura, M., and Inoue, G.: Application of the multi-scale remote sensing and GIS to mapping net primary production in west Siberian wetlands, Phyton, 45, 543-550, 2005.

Peregon, A., Maksyutov, S., Kosykh, N. P., and MironychevaTokareva, N. P.: Map-based inventory of wetland biomass and net primary production in western Siberia, J. Geophys. Res.-Biogeo., 113, G01007, doi:10.1029/2007JG000441, 2008.

Peregon, A., Maksyutov, S., and Yamagata, Y.: An image-based inventory of the spatial structure of West Siberian wetlands, Environ. Res. Lett., 4, 045014, doi:10.1088/1748-9326/4/4/045014, 2009.

Petrescu, A. M. R., van Beek, L. P. H., van Huissteden, J., Prigent, C., Sachs, T., Corradi, C. A. R., Parmentier, F. J. W., and Dolman, A. J.: Modeling regional to global $\mathrm{CH}_{4}$ emissions of boreal and arctic wetlands, Global Biogeochem. Cy., 24, GB4009, doi:10.1029/2009gb003610, 2010.

Prigent, C., Papa, F., Aires, F., Rossow, W. B., and Matthews, E.: Global inundation dynamics inferred from multiple satellite observations, 1993-2000, J. Geophys. Res., 112, D12107, doi:10.1029/2006jd007847, 2007.

Romanova, E., Bybina, R., Golitsyna, E., Ivanova, G., Usova, L., and Trushnikova, L.: Wetland typology map of West Siberian lowland scale 1:2500000 GUGK, Leningrad, Russia, 1977.

Romanova, E.: Vegetation cover of West Siberian Lowland, in: Peatland vegetation, edited by: Il'ina, I., Lapshina, E., Lavrenko, N., Meltser, L., Romanove, E., Bogoyavlenskiy, M., and Mahno, V., Science, Novosibirsk, Russia, 138-160, 1985.

Sabrekov, A., Glagolev, M., Kleptsova, I., Machida, T., and Maksyutov, S.: Methane emission from mires of the West Siberian taiga, Eurasian Soil Sci.+, 46, 1182-1193, 2013.

Sabrekov, A. F., Runkle, B. R. K., Glagolev, M. V., Kleptsova, I. E., and Maksyutov, S. S.: Seasonal variability as a source of uncertainty in the West Siberian regional $\mathrm{CH}_{4}$ flux upscaling, Environ. Res. Lett., 9, 045008, doi:10.1088/1748-9326/9/4/045008, 2014.

Schroeder, R., Rawlins, M. A., McDonald, K. C., Podest, E., Zimmermann, R., and Kueppers, M.: Satellite microwave remote sensing of North Eurasian inundation dynamics: development of coarse-resolution products and comparison with high-resolution synthetic aperture radar data, Environ. Res. Lett., 5, 015003, doi:10.1088/1748-9326/5/1/015003, 2010.
Schroeder, R., McDonald, K. C., Chapman, B. D., Jensen, K., Podest, E., Tessler, Z. D., Bohn, T. J., and Zimmermann, R.: Development and Evaluation of a Multi-Year Fractional Surface Water Data Set Derived from Active/Passive Microwave Remote Sensing Data, Remote Sensing, 7, 16688-16732, 2015.

Sheng, Y., Smith, L. C., MacDonald, G. M., Kremenetski, K. V., Frey, K. E., Velichko, A. A., Lee, M., Beilman, D. W., and Dubinin, P.: A high-resolution GIS-based inventory of the west Siberian peat carbon pool, Global Biogeochem. Cy., 18, GB3004, doi:10.1029/2003gb002190, 2004.

Solomeshch, A.: The West Siberian Lowland, The world's largest wetlands: ecology and conservation, Cambridge University Press, Cambridge, 11-62, 2005.

Solomon, S., Dahe, Q., Martin, M., Melinda, M., Kristen, A., Melinda M.B. , T., Henry, L. M., and Zhenlin, C.: Climate change 2007-the physical science basis: Working group I contribution to the fourth assessment report of the IPCC, Cambridge University Press, 2007.

Song, C., Woodcock, C. E., Seto, K. C., Lenney, M. P., and Macomber, S. A.: Classification and change detection using Landsat TM data: when and how to correct atmospheric effects?, Remote Sens. Environ., 75, 230-244, 2001.

Tiner, R. W., Lang, M. W., and Klemas, V. V.: Remote Sensing of Wetlands: Applications and Advances, CRC Press, 2015.

Turetsky, M. R., Kotowska, A., Bubier, J., Dise, N. B., Crill, P., Hornibrook, E. R., Minkkinen, K., Moore, T. R., Myers-Smith, I. H., Nykanen, H., Olefeldt, D., Rinne, J., Saarnio, S., Shurpali, N., Tuittila, E. S., Waddington, J. M., White, J. R., Wickland, K. P., and Wilmking, M.: A synthesis of methane emissions from 71 northern, temperate, and subtropical wetlands, Glob. Change Biol., 20, 2183-2197, doi:10.1111/gcb.12580, 2014.

Usova, L.: Aerial photography classification of different West Siberian mire landscapes, Nestor-History, Saint-Petersburg, 83 pp., 2009.

Velichko, A. A., Timireva, S. N., Kremenetski, K. V., MacDonald, G. M., and Smith, L. C.: West Siberian Plain as a late glacial desert, Quatern. Int., 237, 45-53, doi:10.1016/j.quaint.2011.01.013, 2011.

Watts, J. D., Kimball, J. S., Bartsch, A., and McDonald, K. C.: Surface water inundation in the boreal-Arctic: potential impacts on regional methane emissions, Environ. Res. Lett., 9, 075001, doi:10.1088/1748-9326/9/7/075001, 2014.

Whitcomb, J., Moghaddam, M., McDonald, K., Kellndorfer, J., and Podest, E.: Mapping vegetated wetlands of Alaska using L-band radar satellite imagery, Can. J. Remote Sens., 35, 54-72, 2009.

Zuffada, C., Li, Z., Nghiem, S. V., Lowe, S., Shah, R., Clarizia, M. P., and Cardellach, E.: The rise of GNSS reflectometry for Earth remote sensing, in: Geoscience and Remote Sensing Symposium (IGARSS), 2015 IEEE International, 5111-5114, IEEE, 2015. 